\title{
ORIGINAL RESEARCH \\ Barriers and Challenges in Managing Hypertension in Belitung, Indonesia: A Qualitative Study
}

Yupin Aungsuroch ${ }^{1}$, Joko Gunawan ${ }^{1}$, Rapin Polsook¹, Sakuntala Anuruang ${ }^{1}$, Sitha Phongphibool², Nazliansyah Nazliansyah 3

${ }^{1}$ Faculty of Nursing, Chulalongkorn University, Bangkok, Thailand

${ }^{2}$ Faculty of Sport Science, Chulalongkorn University, Bangkok, Thailand

3Politeknik Kesehatan Kementerian Kesehatan Pangkal Pinang, Bangka Belitung, Indonesia

\begin{tabular}{l}
\hline Article Info \\
\hline Article History: \\
Received: 20 October 2021 \\
Revised: 23 November 2021 \\
Accepted: 25 November 2021 \\
Online: 27 December 2021 \\
Keywords: \\
Community nurses; hypertension; \\
Indonesia; public health; \\
qualitative research \\
Corresponding Author: \\
Yupin Aungsuroch \\
Faculty of Nursing, Chulalongkorn \\
University, Bangkok, Thailand \\
Email: yupin.a@chula.ac.th
\end{tabular}

\begin{abstract}
Background: The Government of Indonesia has provided a Chronic Disease Management Program, better known as PROLANIS, to reduce the incidence of hypertension; however, the prevalence of hypertension remains high in the community, especially in Belitung, Indonesia, which warrants further investigation. One of the strategies to decrease the number of hypertensions is by addressing barriers and challenges in hypertension management according to patients' points of view, which has become a lack of focus in previous studies.

Purpose: This study aimed to explore the barriers and challenges of patients in managing hypertension in Belitung, Indonesia.

Methods: This research employed a qualitative descriptive study design with 20 hypertensive patients who had access to the PROLANIS program in public health centers. Focus group discussions were conducted for data collection. The content analysis was used for data analysis.

Results: Six themes were developed from the data, including (1) Dietary habits: the role of salt, (2) Nonadherence to medication due to the use of traditional medicine, (3) Shopping habit on nonprescription medication, (4) Confusion of antihypertensive drugs, (5) Barriers to physical exercise, and (6) Health monitoring and education.

Conclusion: This study serves as an input for nurses and healthcare providers to improve the PROLANIS program, especially in hypertension management, as well as to develop new nursing interventions according to the barriers and challenges.
\end{abstract}

How to cite: Aungsuroch, Y., Gunawan, J., Polsook, R., Anuruang, S., Phongphibool, S., \& Nazliansyah, N. (2021). Barriers and challenges in managing hypertension in Belitung, Indonesia: A qualitative study. Nurse Media Journal of Nursing, 11(3), 305-317. https://doi.org/10.14710/nmjn.v11i3.42135

\section{Introduction}

Hypertension is often called a silent killer condition without obvious symptoms in its early stages, which influences the lives of patients (Franklin et al., 2017) and causes comorbidities such as cerebrovascular disease, heart failure, and chronic renal failure (Hakim \& Bagheri, 2014; Kurnia et al., 2018). In addition, hypertension also has an effect on psychological aspects, such as anxiety and depression (Shamsi et al., 2017). A review of trends in hypertension shows that 1.13 billion people living with hypertension in 2015 will be increased to more than 1.56 billion in 2025 worldwide (World Health Organization, 2019).

A high prevalence of hypertension and its close relationship with cardiovascular diseases has become one of the most critical challenges globally, especially in developing countries, such as India, South Africa, Brazil, and Indonesia (Ibrahim \& Damasceno, 2012; Shi et al., 2016). The burden of cardiovascular disease in Indonesia is significant, in which stroke and coronary heart diseases account for more than a third (0.5 million) of all deaths annually, with hypertension being one of the leading causes of mortality (Ministry of Health Republic of Indonesia, 2013; WHO \& UN Partners, 2015).

From the total of 34 provinces in Indonesia, based on Basic Health Research or a communitybased national scale research implemented by the Agency of Health Research and Development, Ministry of Health Republic of Indonesia, Bangka Belitung province has the highest prevalence of hypertension than the other provinces, in terms of the absolute number of people, with a total of 1,380,762 (30.9\%) (Ministry of Health Republic of Indonesia, 2013, 2018). 
One of the efforts conducted by the Government of Indonesia in reducing hypertension is by providing a Chronic Disease Management Program, better known as PROLANIS (or Program Pengelolaan Penyakit Kronis). It was started in 2010 by the Health Insurance Company (or called ASKES, national social insurance covering government employees and military of nearly $20 \%$ of the population of Indonesia) as a proactive approach in reducing chronic diseases, especially diabetes mellitus (DM) type 2 and hypertension (Soewondo et al., 2013). The program is designed to improve quality of life and empower beneficiaries to manage chronic health problems, especially hypertension, diabetes mellitus, cardiovascular diseases, and chronic renal disease. The PROLANIS is continued by the National Social Insurance Administration Organization (or called BPJS) and spearheaded by primary care physicians (BPJS Health, 2014).

There are five activities of PROLANIS mainly conducted in public health centers or called Puskesmas, namely: 1) Consultation of PROLANIS participants: a scheduled consultation mutually agreed between participants and health care providers, 2) Education of PROLANIS participant groups to increase health knowledge in an effort for the treatment and prevention of recurrences of the disease as well to improve the health status of participants, 3) Reminder via Short Message Service (SMS) gateway to motivate participants to do regular visits to health care providers through a schedule reminder consultation, 4) Home visit, a service activity visits to PROLANIS participants' homes for the provision of information, self-health education and environment, and 5) PROLANIS gymnastics, an effort to improve health maintenance and increase physical activity through sport or gymnastics activities conducted with a frequency of once per week (BPJS Health, 2014). However, the PROLANIS activities are expected to effectively reduce the number of patients with hypertension and diabetes mellitus.

Most of the PROLANIS activities are conducted in public health centers. Our literature review with a date range between 2017 and 2021 indicated that numerous studies discussed PROLANIS and hypertension in Indonesia. The local studies have revealed that the PROLANIS program had a significant effect on lowering hypertension, as the study results of pre-experimental studies (Arsyad, 2017; Ningsih, 2017; Sidiq, 2019; Syamson et al., 2020; Herwati \& Delima, 2021; Rani \& Farhan, 2021), quasi-experiments (Armawati \& Eha, 2018; Fahlevi et al., 2019), and a casecontrol study (Dyanneza \& Tamtomo, 2017). But, although the impacts of PROLANIS sound promising, hypertension remains the problem in the community. To the best of our knowledge, in terms of a quantitative strand, none of the recent studies have employed a true-experimental design in examining the effect of PROLANIS on hypertension. Instead, most of the studies used a pre-experimental method in limited settings that might not be sufficient to conclude the findings. Also, most existing studies mainly focused on specific PROLANIS activity, especially PROLANIS exercise or gymnastics on hypertension (Lumempouw et al., 2016; Armawati \& Eha, 2018; Sidiq, 2019) rather than the PROLANIS program as a whole.

In addition, local studies using a qualitative design have been identified in the literature, which aimed to evaluate the PROLANIS implementation in the healthcare centers. The results have revealed that the PROLANIS programs were not yet optimal. Several issues were found, which can be grouped into lack of funding for PROLANIS activities (Manalu, 2017; Firdaus, 2018; Silitonga, 2020; Wardani, 2020; Rachmawati, 2021; Syafitri, 2021), no standard procedures for PROLANIS implementation (Manalu, 2017; Firdaus, 2018; Silitonga, 2020; Wardani, 2020; Isnadia et al., 2021; Rachmawati, 2021), lack of staff (Silitonga, 2020; Wardani, 2020; Syafitri, 2021), lack of socialization (Rachmawati, 2021), inconsistent schedule for the activities (Syafitri, 2021), poor facilitation (Silitonga, 2020; Rachmawati, 2021), unclear job description among staff (Ilahi, 2019; Silitonga, 2020), bureaucracy (Ilahi, 2019; Silitonga, 2020), communication (Ilahi, 2019; Silitonga, 2020), low participations and adherence from the participants (Manalu, 2017). These are significant issues that need to be solved for the successful implementation of the PROLANIS program.

However, the existing qualitative studies mentioned above most likely focused on PROLANIS management rather than hypertension management, although it is closely related. In addition, the findings were mostly according to healthcare staff perceptions rather than the patients' perspectives in addressing their barriers and challenges in managing hypertension. As a matter of fact, understanding the patients' views is a necessity to see a different angle point of the problems, which may also be related to their cultural contexts/issues. In addition, to our knowledge, none of the studies have been conducted in Belitung, Indonesia, on the barriers and challenges in hypertension management among patients, which limit the presentation of other 
cultural and managerial problems in Indonesia. Therefore, this study aimed to explore the barriers and challenges in managing hypertension among patients who had access to the PROLANIS program in public health centers in Indonesia. The findings of our study are expected to be an input for the PROLANIS program, particularly for developing an effective nurse intervention in order to decrease the prevalence of hypertension, as well as for a basis for an experimental study that should fit with the patients' context.

\section{Methods}

\subsection{Research design}

This study used a qualitative descriptive design phenomenological outlined by Lambert and Lambert (2012) to explore the barriers and challenges in managing hypertension in patients who had access to the PROLANIS program in Indonesia. To report the results of this study, the Consolidated criteria for Reporting Qualitative Research (COREQ) checklist (Tong et al., 2007) was used.

\subsection{Setting and participants}

Public health centers were selected as the primary sources of revenue for local governments of Indonesia and are considered agents for carrying community health programs (Hull, 2015). There are nine public health centers in Belitung region, and three public health centers were selected in this study, which were located in different settings, both in the central city of Belitung and rural area of Belitung. This study was conducted in April 2018. Twenty patients were selected using a purposive sampling method. The inclusion criteria of the respondents were adult patients with hypertension, having access to the PROLANIS program, and having uncontrolled or poorly managed hypertension. The uncontrolled or poorly managed hypertension is determined when blood pressure starts from 140 (systole) and/or $90 \mathrm{mmHg}$ and more (diastole). According to Wang and Vasan (2005), a criterion for control is defined as blood pressure $<140 / 90 \mathrm{~mm} \mathrm{Hg}$ at $>75 \%$ of visits.

\subsection{Data collection}

Data were collected using Focus Group Discussions (FGDs) among patients with hypertension in April 2018. Prior to data collection, the researchers sent a letter to each public health center to inform the objective and procedure of the study after being given study approval. Once the directors of public health centers had permitted collecting data, the researchers were asked to contact the in-charge nurses responsible for the hypertension program. The nurses then checked the schedule, availability, and willingness of each patient and made an appointment for FGDs.

FGDs among patients were used to provide an interactive setting with open and enjoyable discussion to gather the patients' opinions, experiences, and beliefs related to hypertension. Another reason was that most patients felt shy (prior to data collection) talking with the investigators through a private and direct interview, and they preferred to discuss their perspectives among their friends (other patients), so they could freely express their thoughts and experiences.

FGDs were done three times in three different groups in different public health centers, with 20 patients. The first group consisted of seven persons, the second group comprised seven persons, and the third group consisted of six persons. The FGD ranged from 50 to 100 minutes. The FGDs were conducted after each participant signed informed consent. There was no one refused to participate in this study.

Bahasa Indonesia or Belitung language was used during the FGDs. Two researchers conducted FGDs, namely, J.G and N.N. During FGDS, N.N also acted as an interpreter for the other researchers for clarity and further discussions. The informants in this study were initially asked an open-ended question. All questions in Table 1 were just examples; more questions were asked following the answers from the respondents and continued until the data reached saturation, especially when the researchers heard the same comments repeatedly.

The FGDS were audio-recorded, transcribed verbatim, and validated by re-listening to the recording by researchers. In addition, all researchers analyzed, reviewed, and discussed each interview and transcript collaboratively. The participants were coded from P1 to P20. 
Table 1. Question guidelines

Questions to ask patients

- Please tell me how you manage your hypertension?

- What kind of strategies do you use at home to manage your symptoms?

- Do you have a diet program to control hypertension and DM?

- How do you manage your food with your family?

- What kind of food do you like?

- Do you join the exercise program at the public health center? Are you also doing exercises at home?

- Do nurses explain about your diet and program to decrease your blood pressure? Do you follow them? If not, why?

- What are the barriers and challenges to managing your diet, exercise, and lifestyle?

- Do you take medicine following the order of health practitioners?

- When the drugs run out, do you come to public health centers again to control or just buy the pills yourself?

- How often do you control your blood pressure? How and where?

\subsection{Data analysis}

The data were analyzed using a content analysis approach outlined by Vaismoradi et al. (2013), which consists of transcribing each interview, reading the transcripts repeatedly to get to the themes by highlighting the codes in the significant excerpts to grasp the meaning units, and organizing the meaning units under subthemes and themes (Vaismoradi et al., 2013). All textual data, including themes or findings, were translated from the Indonesian language into English in the text for data analysis. It was necessary because the other researchers (Y.A., R.P., S.A., and S.P) are non-Indonesians. The translation decisions were guided by the framework of Abfalter et al. (2020), which the translation was done in all stages of the research.

\subsection{Trustworthiness}

Internal member checking (in the form of thematic results, not a full report) was done after the FGDs by the principal investigators to ensure trustworthiness. Member checking is considered the most critical technique to establish the credibility of a qualitative study (Gunawan, 2015). Comparing and contrasting the findings with experienced researchers were also done to prevent personal bias and ensure the quality of data. It is also noted all methodological issues and decisions were documented. This audit trail was made for almost four weeks.

\subsection{Ethical considerations}

The study approval was obtained from the Local Research Ethics Committee of the Department of Health of Tanjung Pandan, Belitung, Indonesia (reference number: 440/1325/ DINKES). The study permission was also obtained from the Public Health Centers where the study took place. All participants were informed of and signed written informed consent for their participation in this study. They were informed about the objective of the research, and their participation was voluntary. All data remained confidential and would be published anonymously.

\section{Results}

\subsection{Characteristics of participants}

The majority of the participants in this study were females, with an average age of 56.6 years. Most of them had a low educational background, and all were married. Fifty percent of the participants had hypertension for five to ten years, with an average of 6.33 years. Forty-five percent had comorbidities such as heart disease, diabetes mellitus, and stroke (Table 2). 
Table 1. Characteristics of patients with hypertension $(n=20)$

\begin{tabular}{lccc}
\hline Characteristics & Mean \pm SD & f & $\%$ \\
\hline Gender & & 1 & 5 \\
$\quad$ Male & & 19 & 95 \\
Female & $56.6 \pm 10.29$ & & \\
Age (year) & & 10 & 50 \\
Education & 3 & 15 \\
$\quad$ Elementary school & 7 & 35 \\
$\quad$ Junior high school & & \\
$\quad$ Senior high school & 20 & 100 \\
Marital status & 0 & 0 \\
$\quad$ Married & & \\
$\quad$ Single & 8 & 40 \\
Duration of hypertension & $6.33 \pm 2.95$ & 11 & 50 \\
$\quad<5$ years & 1 & 5 \\
$5-10$ years & & \\
$\quad>10$ years & 11 & 55 \\
Other diseases & 9 & 45 \\
$\quad$ No & & & \\
$\quad$ Yes (Heart disease, diabetes & & & \\
mellitus, stroke) & & & \\
\hline
\end{tabular}

\subsection{Analytical findings}

There were six themes developed from the data, including (1) Dietary habits: the role of salt, (2) Nonadherence to medication due to the use of traditional medicine, (3) Shopping habit on nonprescription medication, (4) Confusion of antihypertensive drugs, (5) Barriers to physical exercise, and (6) Health monitoring and education. The themes represent new challenges and barriers in hypertension management according to the patients' perspectives. Those themes are described with exemplars from the participants' quotes.

\subsubsection{Theme 1: Dietary habit: The role of salt}

The majority of the patients knew that controlling diet, such as not eating salty, fatty, and unhealthy food, was very important, but it was hard for them to follow. This has become a dietary habit among the patients in this study. They prefer not to follow the restrictive diet, making them uncomfortable. Unhealthy foods are described as foods with less nutritional value and high in fat, sugar, and calories, mostly included in snacks, fats, "fast" foods, cream-based sauces, and others.

The participants expressed their dietary habits in the following statements: If I eat an instant noodle, I just add salt inside it. If not salty, it does not taste good. I know it is dangerous, but I love it (p1, FGD 1), AND I still cannot control my food; although I know I cannot eat salty and fatty foods, I still eat them, but not every day (B6, FGD 3).

Most of the participants were able to cook and prepare their meals. Still, no one was able to avoid salt in their food. The participants said: It is difficult to manage hypertension, especially to handle not eating salty food although we cook by ourselves. It is not delicious without salt (p2, p3, FGD 2).

\subsubsection{Theme 2: Nonadherence to medication due to the use of traditional medicine}

The participants mostly used traditional medicine to manage hypertension, either combined with or replacing prescribed medications. For example, the participant expressed that she used traditional leaves mixed with water for a daily drink: I eat "Daun Suji" (Dracaena Angustifolia leave) when my blood pressure is high. Seven leaves are pounded, mixed with water, and drink two times per day for three days. It is how Sensei from Chinese medicine told me (p1, FGD 1). And, she also said: I use this traditional medicine in combination with the medication given by the public health center (p1, FGD 1).

The other participant used traditional medicine by combining fruits, leaves, and beans for the treatment. She said: cucumber, star fruit, three celery, three yardlong beans, and eat them 
together at night for hypertension (p5, FGD 1). She also expressed: I do not drink the prescribed drugs if I use this medicine. Yeah, I cannot mix them (p5, FGD 1).

\subsubsection{Theme 3: Shopping habit on nonprescription medication}

Some patients had a shopping habit of using nonprescription drugs other than those prescribed by medical doctors in public health centers. This indicates self-medication, in which they bought the drugs directly in the pharmacy following the previous prescription of the physicians with the exact dosage without any assessments. A participant expressed this: I have an available antihypertensive drug (captopril) at my home; I bought it myself from a pharmacy. I showed the drug to the pharmacist, and he gave me those (p2, FGD 1).

Besides, another participant preferred to buy a drug in public shops instead of the kind of drugs given by physicians: If I feel headache, I eat Bodrex (name of the antihypertensive drug in public shops, e.g., Alphamart) (p2, FGD 1).

This self-medication habit is made through generations of the people in Belitung. It is difficult to find those who directly go to public health centers or hospitals without having self-treatment at first. Besides, it is also closely related to the following theme (confusion of antihypertensive drugs) and barriers, such as access to the health centers.

\subsubsection{Theme 4: Confusion of antihypertensive drugs}

Additionally, there was confusion among the patients in taking antihypertensive drugs. Some patients only took the drugs when they knew their blood pressure was elevated, while the others took the medication every day. This confusion is expressed in the following statements: I will have an antihypertensive drug if my blood pressure is high only. If it is not high, I will stop having it (p1, FGD 1); I always consume antihypertensive drugs every time without knowing the symptoms. I just have it (p2, FGD 1); AND which one is true? Taking medicine if high blood pressure or every day without considering how high your blood pressure is? (P1, FGD 1).

Interestingly, this confusion is related to different treatments among public health centers for patients with hypertension, as indicated in this study. One public health center gave antihypertensive medications for three days and asked the patients to return to the center for evaluation. In another public center, the antihypertensive drugs were provided for one month, and there was no drug given to the patients if the blood pressure was not elevated (for those who had hypertension at a previous visit). The participants said: We have antihypertensive drugs from the health center for one week and sometimes one month (B2, FGD 3); when I had myself checked for hypertension, I got antihypertensive drugs for one month in this public health center (A3, FGD 2); AND in this health center if my blood pressure was not high, the drug was not given (p1, FGD 1).

\subsubsection{Theme 5: Barriers to physical exercise}

Although most patients were happy joining the PROLANIS program and were aware that exercise is essential for their health, some could not attend. Several barriers were identified: First, difficult access to the public health center, which is expressed by the participant. I want to go to exercise, but I don't have a motorbike, and no one sent me (B2, FGD 3).

Second, unsuitable exercise for the elderly. This is expressed in the following statement: I am too old to exercise, and the exercise that is conducted every Friday is for young people only (A4, FGD 2); I rarely join the exercise in this public health center, just walking in the morning, but not routine (A2, FGD 2).

Third, it is related to the participants' motivation. Not all individuals like to do exercise, and some might feel lazy and need some supports. The participant expresses this: I am a bit lazy and bored to exercise. But nurses always call me to join the exercise (B1, FGD 3).

\subsubsection{Theme 6: Health monitoring and education}

There was a lack of health monitoring and education for hypertension in public health centers. From the three public health centers in this study, only one public health center has done the health monitoring and education for hypertension in the community. They work closely with elderly integrated health posts or Posbindu lansia.

Regarding health monitoring, the participants expected that the nurses would regularly come to their homes to check their conditions. Participants expressed this: Sometimes, there is a nurse 
who comes to my home to check my blood pressure (pick-up program) ( $\mathrm{P}_{3}$, FGD 1); Today, no one from the health center comes to our home (P4, FGD 2). I think it is good if a nurse comes to our house to control (A3, FGD 2); we expect nurses to visit us and check our health routinely (B2, FGD 3).

The participants also expected that health education could be conducted regularly. Only one public health center provided health education, but it was only performed once per month, while the other public health centers did not offer any. This is expressed by the participants. I do not think there is a problem in the health center, we do exercise and check for their hypertension, but there is no health education and seminar (p3, FGD 1); AND lack of health education in this health center, only one time per month (p3, p4 FGD 1).

\section{Discussion}

This study explored the barriers and challenges of managing hypertension among patients who had access to PROLANIS in Belitung, Indonesia. Six themes were developed from the data analyzed based on the qualitative descriptive approach. The themes include dietary habits: the role of salt, nonadherence to medication due to traditional medicine use, shopping habit on nonprescription medication, the confusion of antihypertensive drugs, physical exercise barriers, and health monitoring and education.

The theme "dietary habit: the role of salt" reflects that the patients with hypertension in Belitung, Indonesia, did not adhere to the restrictive diet although they had knowledge about hypertension and were aware of the impact of an unhealthy diet on their condition. The restrictive diets can place individuals outside of a culture for which salty foods are commonplace. In fact, Belitung, the setting of this study, has a unique and popular culinary food called gangan (yellow fish soup with pineapples) and taoge ikan asin (stir-fried bean sprouts with salted fish) (Aprionis, 2020), which are typically consumed by the participants in this study. In addition, food that is normal and familiar can be a much easier choice and a much more comfortable way of being in the world and fitting in, despite the risks. Having hypertension focuses on salty food, changing the meaning of experiences related to food/eating. This is similar to another part of Indonesia, at Minangkabau Payakumbuh, where people like to eat salty and high-fat food; thus, it serves as a barrier to managing hypertension (Kurnia et al., 2018). Also, in a study in Bangladesh, the patients with hypertension were aware that they should restrict salt intake, but most failed to practice it (Jahan et al., 2020).

Additionally, this finding was in line with a previous study that implied that adherence might not be affected by knowledge (Jolles et al., 2013), or perhaps, it is just to a limited extent of behavioral change (Mooney \& Franks, 2011). Besides, the PROLANIS program provided by the Government of Indonesia does not provide the diet program, as mentioned in the background. The program only focuses on exercise, which might limit the effectiveness of prevention and controlling hypertension. Therefore, according to the study findings, it is recommended for the public health centers to provide a diet program, which may be related to healthy food consumption, nutrition, and healthy cooking. It is noteworthy that the diet program must be planned and monitored, not only limited to the diet education and eating plan. This is an additional suggestion for the studies that just recommended diet education according to DASH (Dietary Approach to Stop Hypertension) eating plan (Dyanneza \& Tamtomo, 2017; Herwati \& Delima, 2021).

The second theme "nonadherence to medication due to the use of traditional medicine" indicates the poor medication adherence or compliance of the community, either they combine with or replace the prescribed medicines, which reflects another barrier in managing hypertension. It is similar to a previous study, which revealed that nonadherence to medication because of the use of traditional medicine is one of the barriers in hypertension management (Gebrezgi et al., 2017). It is undeniable that people in Indonesia not only believe in conventional medicine (Ritonga et al., 2017) but also in shaman for the medication (Sherliawati, 2014). It is in line with a study in rural Yogyakarta, Indonesia, which also found that the patients with hypertension tend to have the preference to manage hypertension on their own, especially to use traditional or alternative medicines and herbs, such as cucumber, avocado leaves (Rahmawati \& Bajorek, 2018), aloe vera (Yuliawati et al., 2021), celery leaves (Isnainy et al., 2021), cupping therapy (Darmawan et al., 2017), acupuncture (Hidayah et al., 2021), and others to replace the prescribed medication. Therefore, during the assessment of patients with hypertension, nurses 
need to ask whether the patients use traditional medicine or combine it with the prescribed drugs before visiting public health centers to improve shared understanding and decision-making.

The third theme is related to the shopping habits on nonprescription drugs, which is common among people in Belitung, Indonesia. They most likely follow a previous dosage of the antihypertensive medications without further evaluation. This shopping habit is not only for the treatment of hypertension but also for all treatments of diseases. The community prefers to try self-treatment first or follow the medication from their friends or family members' experience before directly going to the public health centers. Another reason to do this is most likely related to the next theme (confusion of antihypertensive medicine). However, this will lead to ineffective medication, adverse events, and, in some cases, death. In addition, nonprescription drugs can be misused or abused and can be intentional or unintentional. From these patients' perspectives, health practitioners in public health centers, especially pharmacists, are in an ideal position to help deter misuse and abuse (Ferreri, 2016).

The theme "confusion of antihypertensive drugs" reflects the lack of understanding about the "chronicity" of hypertension and lack of communication about medications between health care providers and patients. The majority of patients were confused about how to take hypertensive medicines. Some of the patients took pills regularly, and some took them only when the symptoms occurred. This is in line with findings from a previous study that, at the same time, every day the patients did not take medication (Cazorla \& Rodríguez, 2013), and most of these patients had stopped taking the medication without consulting their doctor when the blood pressure was in the normal range or when the symptoms of hypertension were reduced (Marshall et al., 2012; Shamsi et al., 2017). It is suggested that nurses need to give the information that medication adherence is the key success of hypertension management, and they need to point out that symptoms are not a key indicator of high blood pressure (Kronish et al., 2012). In addition, the confusion of patients is related to the meaning of "normal" blood pressure, which may be defined as "cured" and cause patients to modify or stop medication (Kronish et al., 2012). Therefore, the use of "controlled" should be more accurate for patients with chronic illnesses like hypertension (Kronish et al., 2012). In addition, this confusion is closely related to the different treatments among public health centers, which has become a new topic or unique findings among patients in treating hypertension. The health practitioners need to emphasize that the medication for hypertension is seen on an individual basis, different from one patient to another, considering comorbid conditions in each patient (Passarella et al., 2018). However, based on the patients' perspectives, there is a need for the health practitioners to discuss with each other to address this issue to avoid misunderstanding and mistreatment of their patients.

The theme "barriers to physical exercise" indicates a need for public health centers to reconsider and remake the exercise program to be "fit" and attractive to all generations. As the patients in this study indicated, the exercise program might not be suitable for the elderly. In addition, nurses need to assess the low and high risks of patients doing physical activity. However, physical exercise can reduce their blood pressure (Diaz \& Shimbo, 2013). In addition, access to public health centers should be considered, especially for the elderly who cannot go to the public health centers on their own. Therefore, the public health centers may need to provide a "pick-up" program to encourage and motivate the patients to join the program. Also, nurses need to provide education to family members to support the patients considering their physical disabilities. Lagu et al. (2015) said that patients with disabilities have physical barriers to access health care. However, family support plays a pivotal role in access to care, exercise, diet, and medication (Shima et al., 2014).

The last theme was developed based on the patients' expectations on health monitoring and education. Only one public health center has a monitoring system for detecting patients with hypertension. In contrast, other two public health centers only have the monitoring system inside the public health center based on those who come to the public centers directly, which might be due to a lack of human resources. In this situation, the public health centers need to set another strategy, such as utilizing cadres from the elderly-integrated health service post or Posbindu lansia to do screening or health visits under the supervision of nurses. Cadre is the village volunteer selected from community members (Nazri et al., 2016). However, training for cadres is needed because health visits require effective communication between patients and health professionals to build trust and increase the knowledge and understanding of patients regarding their conditions and medication regimen (Nazri et al., 2016). 
Besides, the lack of health education was seen from the number of the health education program only provided once per month, which might not be enough to increase the knowledge of patients regarding the disease and its treatment, side effects, and lifestyle behavior. Another strategy for health education should be made, such as health education while the patients are waiting for their treatment. It is unarguable that long waiting is one barrier for the patients to come to the public health centers. The long queue would not be wasting their time with attractive health education but instead giving more knowledge about their disease and treatment. However, it does not mean that long waiting is good for patients; redesigning the queue system is also needed to reduce waiting time.

\section{Implications and limitations}

The findings of this study provide new insight for the management of hypertension for nurses and other healthcare workers and the new inputs for PROLANIS in Indonesia from the patients' perspectives: 1) the study results indicated that the PROLANIS, as well as hypertension management programs worldwide, need to mainly provide and focus on diet practice, diet management, and control. It is known that many patients failed to follow the diet recommendations; 2) from the study findings, it is also suggested for nurses and other healthcare professionals to conduct a patient's assessment regarding the use of traditional medicine in the self-treatment of hypertension. It is necessary because many patients still use, combine, and believe in conventional medicine, which may influence the treatment or nonadherence to the medication. In addition, developing an assessment that focuses explicitly on traditional medicine is needed if the form does not exist; 3) nurses and other healthcare practitioners need to pay attention to the shopping habits of the patients on nonprescription drugs. This is the homework for all health professionals to increase patient awareness to avoid drug misuse and abuse. Besides, the findings of this study also indicated that a discussion among health practitioners is needed to deal with the patients' confusion regarding the treatment. It needs to emphasize that the treatment is done on an individual basis; one medicine or treatment cannot fit all; 4) every healthcare center is demanded to provide an attractive exercise program that includes all generations. It can be one for all, or each population group has its own exercise program. The elderly may not be able to do an aerobic exercise, cardio workout, or fat burning program. This has to be a program for an elderly group; 5) it is recommended for healthcare centers to provide a pick-up service for those who do not have easy access. Sometimes we cannot wait for the patients to come to the centers; we need to see them directly or pick them up to join the healthy program and check-up health. However, human resource strategy needs to be well managed. Utilizing cadres is recommended; 6) health education should be regularly conducted because knowledge changes over time. Updated knowledge and information need to be disseminated to avoid hoaxes and misinformation.

This study has limitations. The findings of this study might not represent the whole Indonesian context because another part of the country may provide other cultural and managerial contexts, which may influence hypertension management. However, it is noteworthy that culture cannot be separated from the treatment. In addition, patients' perspectives might not provide a holistic understanding of PROLANIS management, but their views remain essential as they are the recipients of the healthcare services.

\section{Conclusion}

As hypertension has become a significant public health problem, understanding the patients' perspectives is necessary to provide comprehensive hypertension management. Our findings underscore the barriers and challenges in managing hypertension in one of Indonesia's health care system contexts. Differences and similarities from the patients' views were analyzed and resulted in six themes - dietary habit, use of traditional medicine, shopping habit on nonprescription medication, the confusion of antihypertensive drugs, barriers to physical exercise, and health screening, which should be addressed and solved by healthcare providers, especially healthcare practitioners including community nurses in public health centers in Indonesia and beyond. However, future studies need to address various settings to understand holistically the management of hypertension considering multi-cultures in Indonesia. In addition, an interventional study is also necessary to determine the effect of the combination of diet, exercise, and medication programs on hypertension. 


\section{Acknowledgment}

This study was granted by the Ratchadapisek Sompoch Endowment Fund (2018), Chulalongkorn University, Bangkok Thailand. The authors acknowledge the Department of Health of Belitung, Public Health Center of Tanjung Pandan, Public Health Center of Air Saga, and Public Health Center of Tanjung Binga for all supports. We also appreciate the help of nurses and the participation of the patients in this study.

\section{Author's contribution}

All authors contributed to substantial contributions to conception and design, or acquisition of data, or analysis and interpretation of data. JG and NN contributed to data coders. All authors are also involved in drafting the manuscript or revising it critically for important intellectual content and given final approval of the version to be published. Each author has participated sufficiently in work to take public responsibility for appropriate portions of the content and agreed to be accountable for all aspects of the work in ensuring that questions related to the accuracy or integrity of any part of the work are appropriately investigated and resolved.

\section{Conflict of interest}

The authors declared that there is no conflict of interest in this study.

\section{References}

Abfalter, D., Mueller-Seeger, J., \& Raich, M. (2020). Translation decisions in qualitative research: A systematic framework. International Journal of Social Research Methodology, 1-18. https://doi.org/10.1080/13645579.2020.1805549

Aprionis. (2020). Gangan ikan ketarap dan taoge ikan asin dapat perhatian Menteri Suharso [Ketarap fish yellow soup and stir-fried bean sprouts with salted fish have become the attention of Minister Suharso]. Antara Babel. https://babel.antaranews.com/berita/163510/gangan-ikan-ketarap-dan-taoge-ikan-asindapat-perhatian-menteri-suharso

Armawati, A., \& Eha, S. (2018). Effectiveness of PROLANIS gymnastics on decreasing blood pressure in patients with stage one hypertension, Indonesia. Indian Journal of Forensic Medicine \& Toxicology, 12(3), 297-302. https://doi.org/10.5958/0973-9130.2018.00176.7

Arsyad, G. (2017). Pengaruh PROLANIS terhadap tekanan darah pada penderita hipertensi di Puskesmas Banjardawa Kecamatan Taman Kabupaten Pemalang [Effect of PROLANIS on blood pressure among patients with hypertension in the Public Health Center of Banjardawa, Taman District, Pemalang Regency] [Undergraduate thesis, Universitas Muhammadiyah Semarang]. http://repository.unimus.ac.id/870/

BPJS Health. (2014). Panduan praktis PROLANIS (Program pengelolaan penyakit kronis) [Practical guidelines of PROLANIS (chronic disease management program)]. Badan Penyelenggara Jaminan Sosial.

Cazorla, M., \& Rodríguez, D. (2013). Degree of therapeutic adherence to bone mineral metabolism drugs: Do our patients take the prescribed medication. Enfermería Nefrológica, 16(1), 41-47.

Darmawan, B., Fatmasari, D., Sri, R., \& Pujiastuti, E. (2017). Negative air pressure on wet cupping in decreasing blood pressures in hypertensive patients. Nurse Media Journal of Nursing, 7(2), 116-129. https://doi.org/10.14710/nmjn.v7i2.15177

Diaz, K. M., \& Shimbo, D. (2013). Physical activity and the prevention of hypertension. Current Hypertension Reports, 15(6), 659-668. https://doi.org/10.1007/s11906-013-0386-8

Dyanneza, F., \& Tamtomo, D. (2017). The effectiveness of chronic disease management program in blood pressure control among hypertensive patients. Indonesian Journal of Medicine, 2(1), 52-62. https://doi.org/10.26911/theijmed.2016.01.03.06

Fahlevi, A. R., Riyadi, A., \& Mardiani, M. (2019). Senam PROLANIS menurunkan tekanan darah lansia penderita hipertensi [PROLANIS gymnastics reduces blood pressure of elderly patients with hypertension]. Jurnal Keperawatan Raflesia, 1(2), 119-128. https://doi.org/10.33088/jkr.v1i2.401

Ferreri, S. (2016). Appropriate use of nonprescription drugs: How pharmacists can help. Pharmacy Today, 22(3), 48. https://doi.org/10.1016/j.ptdy.2016.02.023

Firdaus, D. F. S. (2018). Analisis program pengelolaan penyakit kronis (PROLANIS) di Puskesmas Sako Kota Palembang [Analysis of chronic diseases management in the Sako 
Health Center of Palembang City] [Undergraduate thesis, Sriwijaya University]. https://repository.unsri.ac.id/8593/

Franklin, S. S., O'brien, E., \& Staessen, J. A. (2017). Masked hypertension: Understanding its complexity. European Heart Journal, 38(15), 1112-1118. https://doi.org/10.1093/eurheartj/ehw502

Gebrezgi, M. T., Trepka, M. J., \& Kidane, E. A. (2017). Barriers to and facilitators of hypertension management in Asmara, Eritrea: Patients' perspectives. Journal of Health, Population, and Nutrition, 36(1), 11-11. https://doi.org/10.1186/s41043-017-0090-4

Gunawan, J. (2015). Ensuring trustworthiness in qualitative research. Belitung Nursing Journal, 1(1), 10-11. https://doi.org/10.33546/bnj.4

Hakim, A., \& Bagheri, R. (2014). Prevalence of hypertension and associated factors in ahvaz school age children in 2013. International Journal of Community Based Nursing and Midwifery, 2(3), 136.

Herwati, H., \& Delima, D. (2021). Model pendidikan kesehatan diet DASH dan senam hipertensi terhadap tekanan darah penderita hipertensi [Health education model of DASH diet and hypertension exercise on blood pressure in hypertensive patients]. Menara Ilmu: Jurnal Penelitian dan Kajian Ilmiah, 15(1), 2754. https://doi.org/10.31869/mi.v15i1.2754

Hidayah, N., Prabaniarga, V. D., Azizah, H. T., Ramadini, L. Y., Sudiarto, M., Klassen, C., Kontogianni, D., Johari, Z. B., \& Lo, R. (2021). Pijat-Pijat Pancen Oye (PPO): Metode akupresur untuk meringankan gejala hipertensi pada lansia [Pijat-pijat Pancen Oye (PPO): Accupressure method to lowering hypertension symptoms in the elderly]. Journal Health and Science Gorontalo Journal Health and Science Community, 5(1), 188-193. https://doi.org/10.35971/gojhes.v5i1.9927

Hull, T. H. (2015). Reducing maternal and neonatal mortality in Indonesia: Saving lives, saving the future. Bulletin of Indonesian Economic Studies, 51(1), 154-155. https://doi.org/10.1080/ooo74918.2015.1023418

Ibrahim, M. M., \& Damasceno, A. (2012). Hypertension in developing countries. The Lancet, 380(9841), 611-619. https://doi.org/10.1016/s0140-6736(12)60861-7

Ilahi, R. (2019). Implementasi program pengelolaan penyakit kronis (PROLANIS) BPJS Kesehatan di Klinik Pratama Vita Medika Kota Banjar [Implementation of PROLANIS program of BPJS Health at Klinik Pratama Vita Medika Banjar City] [Undergraduate thesis, Siliwangi University]. http://repositori.unsil.ac.id/533/

Isnadia, I., Maryati, H., \& Arsyati, A. M. (2021). Gambaran pelaksanaan program pengelolaan penyakit kronis (PROLANIS) pasien hipertensi di Puskesmas Lawanggintung Kota Bogor tahun 2018 [Description of PROLANIS implementation in hypertensive patients in Lawanggintung Public Health Center, Bogor City in 2018]. PROMOTOR Jurnal Mahasiswa Kesehatan Masyarakat, 4(3), 227-234.

Isnainy, U. C. A. S., Wahyuni, M. S., \& Hermawan, D. (2021). Pemberian rebusan daun seledri untuk menurunkan tekanan darah pada klien hipertensi di Kecamatan Sekampung Mudik Desa Brawijaya [Giving celery leaf decoction to lower blood pressure in hypertensive patients at Sekampung Mudik District, Brawijaya Village]. Jurnal Kreativitias Pengabdian Kepada Masyarakat, 4(4), 2830. https://doi.org/10.33024/jkpm.v4i4.2830

Jahan, Y., Moriyama, M., Rahman, M. M., Kazawa, K., Mizukawa, M., Rahman, A., Shahid, A. S. M. S. B, Das, S. K., Faruque, A. S. G., \& Chisti, M. J. (2020). Disease perception and experiences among rural Bangladeshi hypertensive women: A qualitative approach. Health Promotion Perspectives, 10(1), 66-73.

Jolles, E. P., Padwal, R. S., Clark, A. M., \& Braam, B. (2013). A qualitative study of patient perspectives about hypertension. ISRN Hypertension, 2013, 671691. https://doi.org/10.5402/2013/671691

Kronish, I. M., Leventhal, H., \& Horowitz, C. R. (2012). Understanding minority patients' beliefs about hypertension to reduce gaps in communication between patients and clinicians. The Journal of Clinical Hypertension, 14(1), 38-44. https://doi.org/10.1111/j.17517176.2011.00558.x

Kurnia, V., Suza, D., \& Ariani, Y. (2018). Experience of barriers to hypertension management in Minangkabau Ethnic group in Payakumbuh Indonesia: A phenomenological study. Belitung Nursing Journal, 4(2), 154-16o. https://doi.org/10.33546/bnj.313 
Lagu, T., Griffin, C., \& Lindenauer, P. K. (2015). Ensuring access to health care for patients with disabilities. JAMA Internal Medicine, 175(2), 157-158. https://doi.org/10.1001/jamainternmed.2014.6740

Lambert, V. A., \& Lambert, C. E. (2012). Qualitative descriptive research: An acceptable design. Pacific Rim International Journal of Nursing Research, 16(4), 255-256.

Lumempouw, D. O., Wungouw, H. I. S., \& Polii, H. (2016). Pengaruh senam PROLANIS terhadap penyandang hipertensi [Influence of PROLANIS exercise on hypertensive patients]. Jurnal e-Biomedik, 4(1).

Manalu, P. (2017). Analisis implementasi program pengelolaan penyakit kronis di Gadjah Mada Medical Center Health Center [Analysis of the implementation of chronic disease management program (PROLANIS) in Gadjah Mada Medical Health Center] [Master's thesis, Universitas Gadjah Mada]. http://etd.repository.ugm.ac.id/home/detail_pencarian/116663

Marshall, I. J., Wolfe, C. D., \& McKevitt, C. (2012). Lay perspectives on hypertension and drug adherence: Systematic review of qualitative research. BMJ, 345, e3953. https://doi.org/10.1136/bmj.e3953

Ministry of Health Republic of Indonesia. (2013). Laporan riset kesehatan dasar 2013 [Basic health research report 2013]. Ministry of Health Republic of Indonesia.

Ministry of Health Republic of Indonesia. (2018). Laporan riset kesehatan dasar 2018 [Basic health research report 2018]. Ministry of Health Republic of Indonesia.

Mooney, L. A., \& Franks, A. M. (2011). Impact of health screening and education on knowledge of coronary heart disease risk factors. Journal of the American Pharmacists Association, 51(6), 713-718. https://doi.org/10.1331/japha.2011.10127

Nazri, C., Yamazaki, C., Kameo, S., Herawati, D. M. D., Sekarwana, N., Raksanagara, A., \& Koyama, H. (2016). Factors influencing mother's participation in Posyandu for improving nutritional status of children under-five in Aceh Utara district, Aceh province, Indonesia. BMC Public Health, 16, 69-69. https://doi.org/10.1186/s12889-016-2732-7

Ningsih, I. P. (2017). Pengaruh program pengelolaan penyakit kronis (PROLANIS) terhadap penurunan tekanan darah pada pasien hipertensi berbasis teori caring (Di Puskesmas Bandarkedungmulyo Kabupaten Jombang tahun 2017) [Effect of chronic disease management program (PROLANIS) on decreasing blood pressure in hypertensive patients based on the theory of caring (In Bandarkedungmulyo public health center, Jombang regency in 2017)] [Undergraduate thesis, Sekolah Tinggi Ilmu Kesehatan Insan Cendekia Medika]. https://repo.stikesicme-jbg.ac.id/100/

Passarella, P., Kiseleva, T. A., Valeeva, F. V., \& Gosmanov, A. R. (2018). Hypertension management in diabetes: 2018 update. Diabetes Spectrum, 31(3), 218-224. https://doi.org/10.2337/ds17-0085

Rachmawati, S. (2021). Analisis pelaksanaan program penyakit kronis (PROLANIS) di Kabupaten Sampang [Analysis of PROLANIS program implementation in patients with hypertension at Sampang Regency] [Master's thesis, Universitas Airlangga]. https://repository.unair.ac.id/109601/

Rahmawati, R., \& Bajorek, B. (2018). Understanding untreated hypertension from patients' point of view: A qualitative study in rural Yogyakarta province, Indonesia. Chronic Illness, 14(3), 228-240. https://doi.org/10.1177/1742395317718034

Rani, T. K., \& Farhan, F. S. (2021). Efektivitas senam PROLANIS terhadap perubahan tekanan darah pada peserta senam Prolanis Klinik Cempaka Jakarta Timur [Effectiveness of PROLANIS exercise on blood pressure change in PROLANIS participants in Cempaka Clinic, East Jakarta]. Muhammadiyah Journal of Geriatric, 2(1), 27-32.

Ritonga, N. J., Setiani, O., Umaroh, U., \& Amri, F. (2017). Roselle flower (Hibiscus sabdariffa) in the treatment of hypertension in postpartum mothers. Belitung Nursing Journal, 3(3), 229237. https://doi.org/10.33546/bnj.95

Shamsi, A., Nayeri, N. D., \& Esmaeili, M. (2017). Living with hypertension: A qualitative research. International Journal of Community Based Nursing and Midwifery, 5(3), 219-230.

Sherliawati, W. (2014). Kepercayaan masyarakat terhadap dukun: Studi kasus di lingkungan 5 Kelurahan Yukumjaya Kecamatan Terbanggi Besar Kabupaten Lampung Tengah [Community belief on shaman: A case study on 5 Districts of Yukumjaya, Terbanggi Besar 
Lampung Tengah] [Undergraduate thesis, Universitas Bengkulu]. http://repository.unib.ac.id/9137/

Shi, A., Tao, Z., Wei, P., \& Zhao, J. (2016). Epidemiological aspects of heart diseases. Experimental and Therapeutic Medicine, 12(3), 1645-1650. https://doi.org/10.3892/etm.2016.3541

Shima, R., Farizah, M. H., \& Majid, H. A. (2014). A qualitative study on hypertensive care behavior in primary health care settings in Malaysia. Patient Preference and Adherence, 8, 1597-1609. https://doi.org/10.2147/ppa.s6968o

Sidiq, M. N. (2019). Pengaruh senam PROLANIS terhadap tekanan darah pasien hipertensi di Puskesmas Purwodiningratan Kota Surakarta [Effect of PROLANIS exercie on blood pressure in patients with hypertension at Public Health Center of Purwodiningratan Surakarta] [Undergraduate thesis, Universitas Muhammadiyah Surakarta]. http://eprints.ums.ac.id/72950/

Silitonga, C. K. (2020). Implementasi program pengelolaan penyakit kronis (Prolanis) di wilayah kerja Puskesmas Tegal Sari tahun 2020 [PROLANIS implementation at the working area of Puskesmas of Tegal Sari year 2020] [Undergraduate thesis, Universitas Sumatera Utara]. https://repositori.usu.ac.id/handle/123456789/30241

Soewondo, P., Ferrario, A., \& Tahapary, D. L. (2013). Challenges in diabetes management in Indonesia: A literature review. Globalization and Health, 9(1), 63. https://doi.org/10.1186/1744-8603-9-63

Syafitri, S. (2021). Implementasi program pengelolaan penyakit kronis (PROLANIS) di Puskesmas Padang Bulan Kota Medan tahun 2020 [Implementation of PROLANIS program at Padang Bulan Public Health Center, Medan City year 2020] [Undergraduate thesis, Universitas Sumatera Utara]. https://repositori.usu.ac.id/handle/123456789/43704

Syamson, M. M., Fitri, N., \& Hasrul, H. (2020). Pengaruh senam prolanis terhadap penurunan tekanan darah pada penderita hipertensi [Effect of PROLANIS exercie on lowering blood pressure in hypertensive patients]. Holistik Jurnal Kesehatan, 14(1), 74-81. https://doi.org/10.33024/hjk.v14i1.2330

Tong, A., Sainsbury, P., \& Craig, J. (2007). Consolidated criteria for reporting qualitative research (COREQ): A 32-item checklist for interviews and focus groups. International Journal for Quality in Health Care, 19(6), 349-357. https://doi.org/10.1093/intqhc/mzmo42

Vaismoradi, M., Turunen, H., \& Bondas, T. (2013). Content analysis and thematic analysis: Implications for conducting a qualitative descriptive study. Nursing \& Health Sciences, 15(3), 398-405. https://doi.org/10.1111/nhs.12048

Wang, T. J., \& Vasan, R. S. (2005). Epidemiology of uncontrolled hypertension in the United $\begin{array}{lll}\text { States. } & \text { Circulation, } & 112(11),\end{array}$ https://doi.org/10.1161/CIRCULATIONAHA.104.490599

Wardani, A. E. (2020). Pelaksanaan program pengelolaan penyakit kronis (PROLANIS) pada penyakit hipertensi dan diabetes mellitus tipe 2 di Puskesmas Kabupaten Soppeng [The implementation of chronic disease management program (PROLANIS) for patients with hypertension and diabetes mellitus type 2 in community health center, Soppeng Regency] [Undergraduate thesis, Universitas Hasanuddin]. http://repository.unhas.ac.id/id/eprint/2452/

WHO, \& UN Partners. (2015). Country statistics and global health estimates. http://www.who.int/gho/countries/idn.pdf?ua =1

World Health Organization. (2019). Hypertension. https://www.who.int/news-room/factsheets/detail/hypertension\#: :text=A\%20review\%20of\%20current\%20trends,risk\%2ofact ors\%20in\%20those\%2opopulations.

Yuliawati, V., Vani, A. T., \& Heppy, F. (2021). Korelasi perubahan tekanan darah dengan perubahan kadar kolesterol total pasien PROLANIS yang mendapatkan jus lidah buaya (Aloe vera) [Correlation of blood pressure change with total cholesterol level change in PROLANIS patients who received Aloe vera juice]. Health and Medical Journal, 3(1), 450. https://doi.org/10.33854/heme.v3i1.450

Copyright (C) 2021 NMJN. This article is an open-access article distributed under the terms and conditions of the Creative Commons Attribution-Share Alike 4.0 (CC BY-SA) International License (https://creativecommons.org/licenses/by-sa/4.0). 